\title{
Progesterone Receptor Positive
}

National Cancer Institute

\section{Source}

National Cancer Institute. Progesterone Receptor Positive. NCI Thesaurus. Code C15496.

An indication that progesterone receptor (PRG; PR) expression has been detected in a sample. 